\title{
DECAY PATTERNS AND DAMAGE PROCESSES OF HISTORIC CONCRETE: A SURVEY IN THE NETHERLANDS
}

\author{
G. PARDO REDONDO ${ }^{1 *}$, S. NALDINI ${ }^{2}$ AND B. LUBELLI ${ }^{3}$ \\ ${ }^{1}$ Chair of Heritage \& Architecture, department of Architectural Engineering + Technology \\ Technische Universiteit Delft \\ Julianalaan 134, 2628BL Delft, The Netherlands \\ e-mail: g.pardoredondo@tudelft.nl (*corresponding author) \\ ${ }^{2}$ Chair of Heritage \& Architecture, department of Architectural Engineering + Technology \\ Technische Universiteit Delft \\ Julianalaan 134, 2628BL Delft, The Netherlands \\ e-mail: s.naldini@tudelft.nl \\ ${ }^{3}$ Chair of Heritage \& Architecture, department of Architectural Engineering + Technology \\ Technische Universiteit Delft \\ Julianalaan 134, 2628BL Delft, The Netherlands \\ email: b.lubelli@tudelft.nl
}

Keywords: Historic structures, Concrete, Decay patterns, Damage processes, Assessment

\begin{abstract}
.
Historic concrete buildings (end of 19th century - 1960s), because of their "experimental" character, require a specific approach to both survey and conservation. Although they were built with empirical approaches, some buildings show a fair state of conservation and resilience -even though they have already exceeded the 100-year threshold-while others of comparable age are in severe need of restoration.

As part of the European project CONSECH20, aimed at contributing to the conservation of cultural-heritage concrete buildings, this paper investigates what are the most common types of damage and hypothetical causes, and what direct and non-direct parameters can lead to a faster or slower deterioration of historic concrete in the Netherlands. The research is based on an initial screening study, which will be used as a basis for a larger research among the participant countries.

The current research is divided in three phases. Firstly, a selection of 15 case studies from the Netherlands are investigated; the selection was based on criteria of age, state of conservation and type of ownership. Secondly, the history and materials of the buildings are examined. Thirdly, an on-site visual survey is performed per each building, with predesign templates, to identify types of damage, extent and severity. The data is then analysed combining different factors with a calculated index of severity. Results are discussed and contrasted to provide further clarification of the degradation of historic concrete. A fourth phase, not discussed in this paper, will use this methodology in a broader context, with a larger number of case studies in different countries.
\end{abstract}


The results indicate that the majority of types of damage are related to corrosion, being the hypothetical cause carbonation-induced corrosion. The outcomes of the investigation point out that the factors with a higher impact on the durability are the environment, the use and maintenance of the buildings, the existence of a sacrificial plaster in exposed elements, and the type of ownership.

Considering the limited number of buildings, the conclusions presented in this paper will be further contrasted with a larger number of case studies.

\section{INTRODUCTION}

Reinforced concrete (RC) is a 'young' material, used from the middle of the 19th century onwards. Initially, concrete was a secondary material, used mainly for planters and small objects [1]. By the end of the 19th century, RC was used as structural construction material for not only for modest buildings but for the early skyscrapers [2,3]. By the turn of the century, RC became a primary construction system. After WWII, RC developed into the first global construction materials and thousands of buildings were built worldwide.

As in any ground-braking new

technology, the first reinforced concrete buildings were experimental. There was no experience or a solid scientific knowledge behind these pioneering

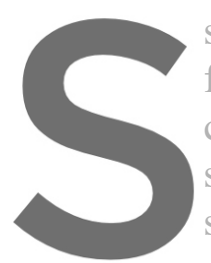
structures. As a result, different design flaws can be now encour concrete constructions sufficient concrete cover suitable materials in $\mathrm{t}$ concrete and steel strength, or poor compaction among others [4].

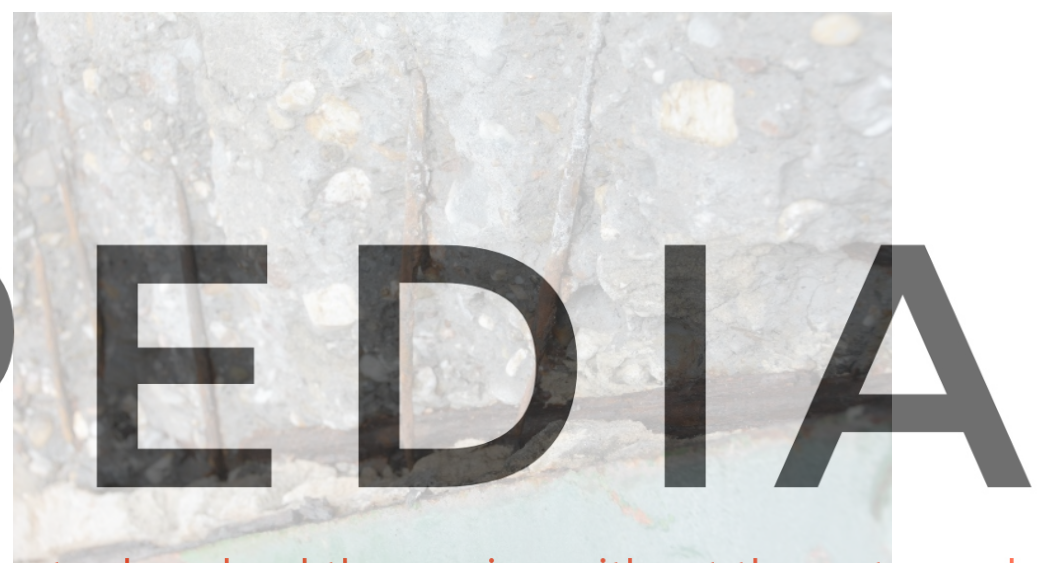

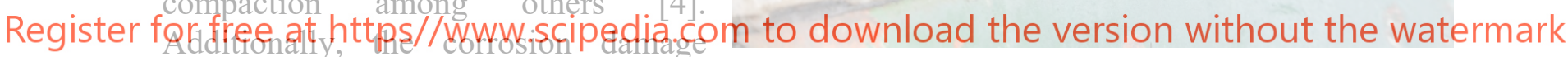
encountered in early RC structures leads

to loss of rebar sections (Figure 1), bond deterioration and cover delamination (spalling), which eventually can affect the structural capacity of the building.

By the end of the 1970s, concrete repairs had become a major issue, but until the 1980s there was not a full understanding of some of the problems affecting RC such as the carbonationinduced corrosion [5]. However, it still took years for the conservation practice to merit cultural heritage $(\mathrm{CH})$ status to concrete buildings. 


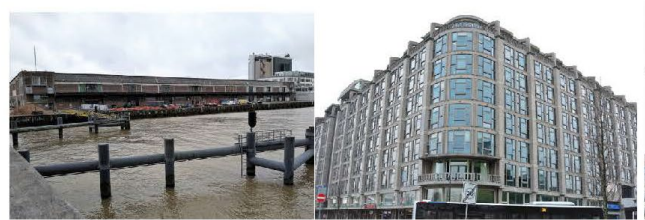

(a)

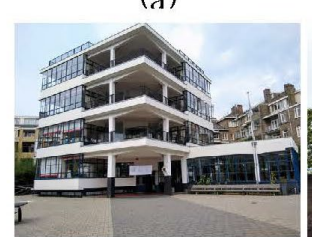

(d) (b)

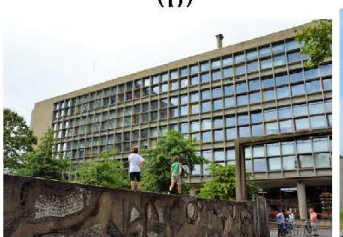

(e)

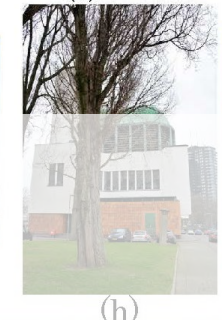

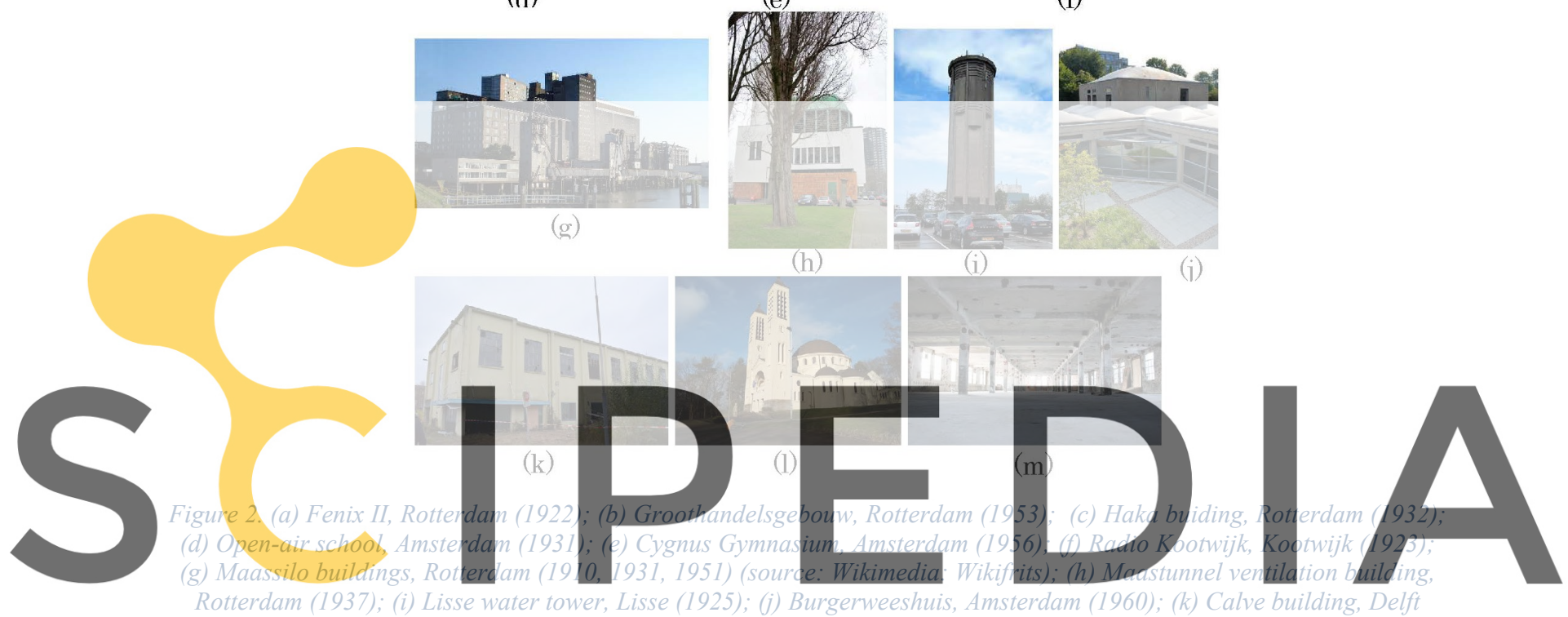

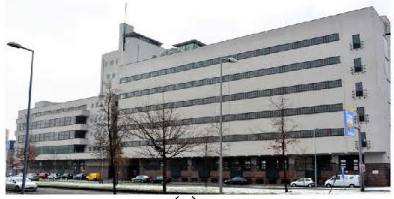

$(c)$

(f)

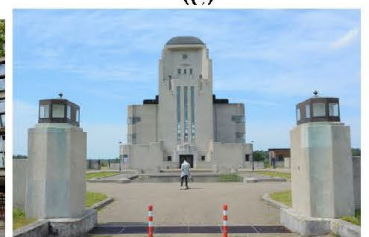

\section{Register for}

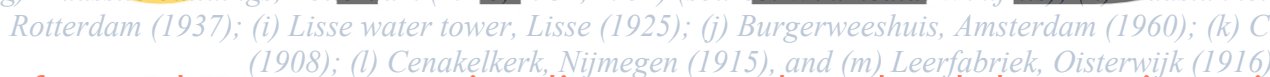

One of the challenges in the (re-)use of historic concrete ${ }^{1}$ buildings is to accurately predict

the ongoing threats and how the buildings will further behave to these threats.

This paper is part of larger research project that aims at developing an improved methodology for the conservation of $20^{\text {th }}$ century $\mathrm{CH}$ concrete buildings. The proposed research is fourfold. Firstly, 15 case studies in the Netherlands will be selected based on age, state of conservation and ownership. Secondly, a background research will be carried out to identify materials, uses, building characteristics, environment, and other parameters. Thirdly, on-site visual assessments will be performed at each building to record damage types, extent and severity. All the input will follow a standardized template previously designed to avoid misinterpretations, and to obtain uniform and comparable data. A severity index, related to the condition of the buildings, will be calculated based on the visual investigation, and contrasted with the different parameters in order to have an indication of the chief parameters affecting durability. Fourthly, a larger number of screening cases, from the participant countries, will be studied following the same methodology, to verify the initial results presented in here. This paper will focus on the first three of these four parts.

\footnotetext{
${ }^{1}$ In this article, the term "historic concrete" refers to reinforced concrete produced before the 1960s.
} 


\section{SCREENING CASES AND ON-SITE ASSESSMENT}

The criteria for the selection of the case studies aimed to have a wellbalanced number of buildings of different age, from the beginning of the $19^{\text {th }}$ century to the $1960 \mathrm{~s}$; a representative number of privately and publicly owned buildings; and similar number of restored and in-need-ofrestoration buildings. These two later parameters were included to have a broader context on the factors influencing the condition of the buildings. Another requirement for the selection of the buildings was that they needed to be accessible.

For each case study, a background investigation was performed about the history of the building and its characteristics (age, location, exposure, type of structure, façade, roof, exposed
elements, finishes over concrete,
materials, etc.). In the field, a visual
assessment was performed to verify the
theoretical investigation and to record
types of damage and their hypothetical

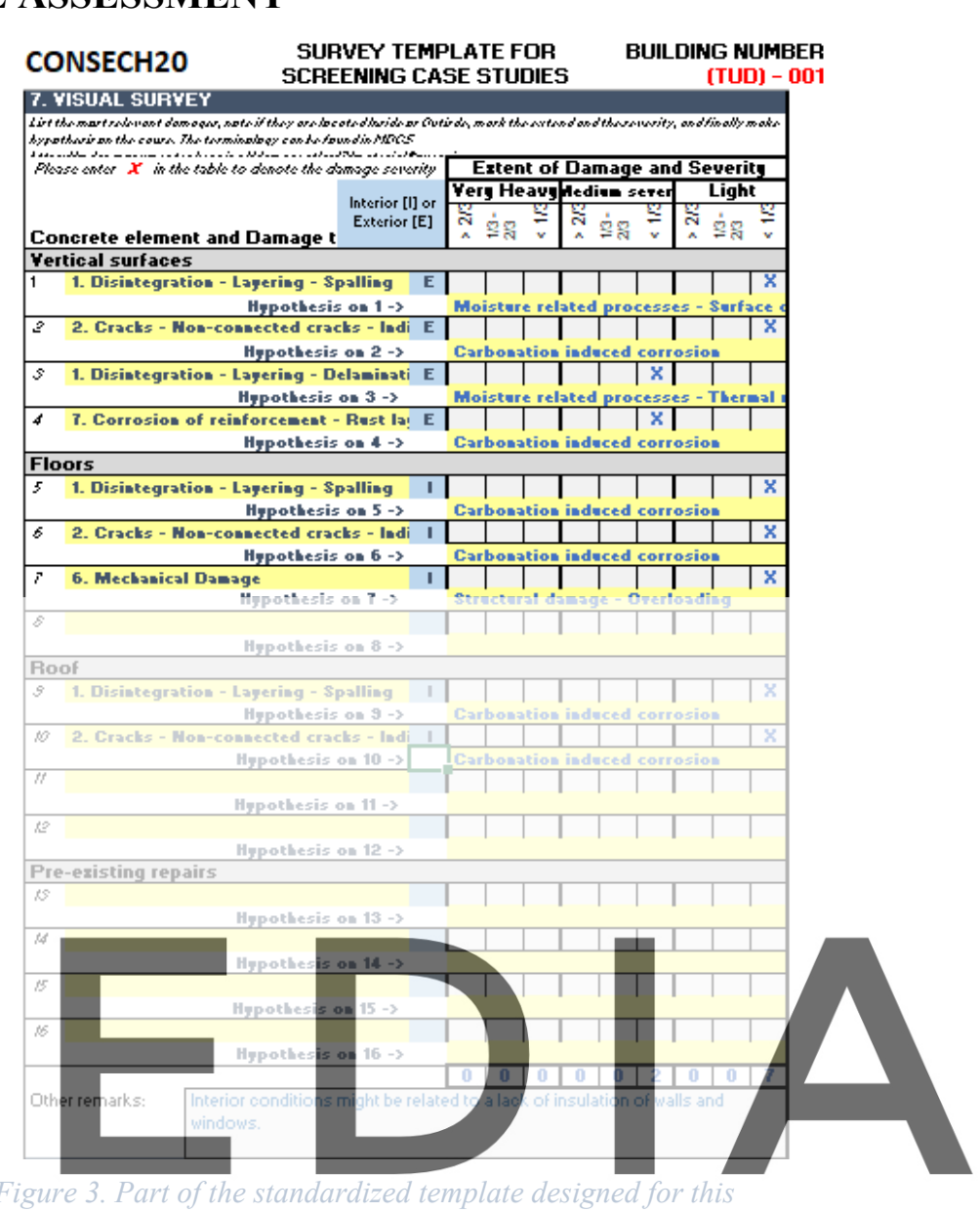
causes, extent and severity. The system

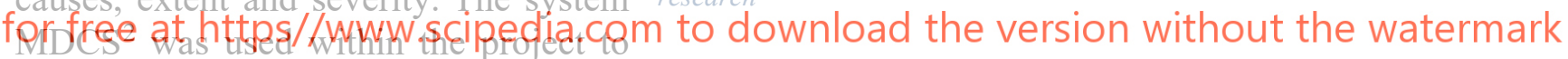
achieve a uniform damage identifictaon.

The information was then conveyed into a standardized spreadsheet template (Figure 2), one per each building, to be used for all partner institutions. The template was based on the synthesis of different assessment forms [6-10]. To guarantee uniform and comparable data, and avoid misinterpretations, the parameters and values were previously agreed upon with the partners and programmed so that they could only be selected from a dropdown menu when entering the information in the spreadsheet.

\section{RESULTS: COMMON DAMAGES AND FACTORS INFLUENCING DURABILITY OF HISTORIC CONCRETE}

The investigation of the case studies in the Netherlands resulted in the following building characteristics:

- $40 \%$ of the investigated buildings were classified as "restored", and $40 \%$ of the buildings were classified as "in need of repair", the remaining $20 \%$ were classified as

\footnotetext{
${ }^{2}$ MDCS https://mdcs.monumentenkennis.nl
} 
"Fair" and "Others".

- The original uses of the buildings were warehouses (33\%), production/factories $(20 \%)$ education $(20 \%)$, and other uses $(27 \%)$ The present uses of the buildings included business (33\%), offices (20\%), and not used - abandoned (20\%), and other uses $(27 \%)$.

- $67 \%$ of the buildings were privately owned, and 33\% publicly owned.

- $87 \%$ had concrete elements exposed to the outdoors; from those, $69 \%$ were plastered, with at least $1 \mathrm{~cm}$ of cement mortar, and $31 \%$ were not plastered.

Regarding the types of damage and their hypothetical causes, the recorded results were:

- Spalling (26\%), uniform corrosion/rust layers (19\%) and non-connected cracks (17\%). The rest of the damage types were scattered representing $4 \%$ or less (Figure 4 ).

- $85 \%$ of the damages were classified as "Light", $15 \%$ as "Medium Severe", and $0 \%$ as Very Heavy.
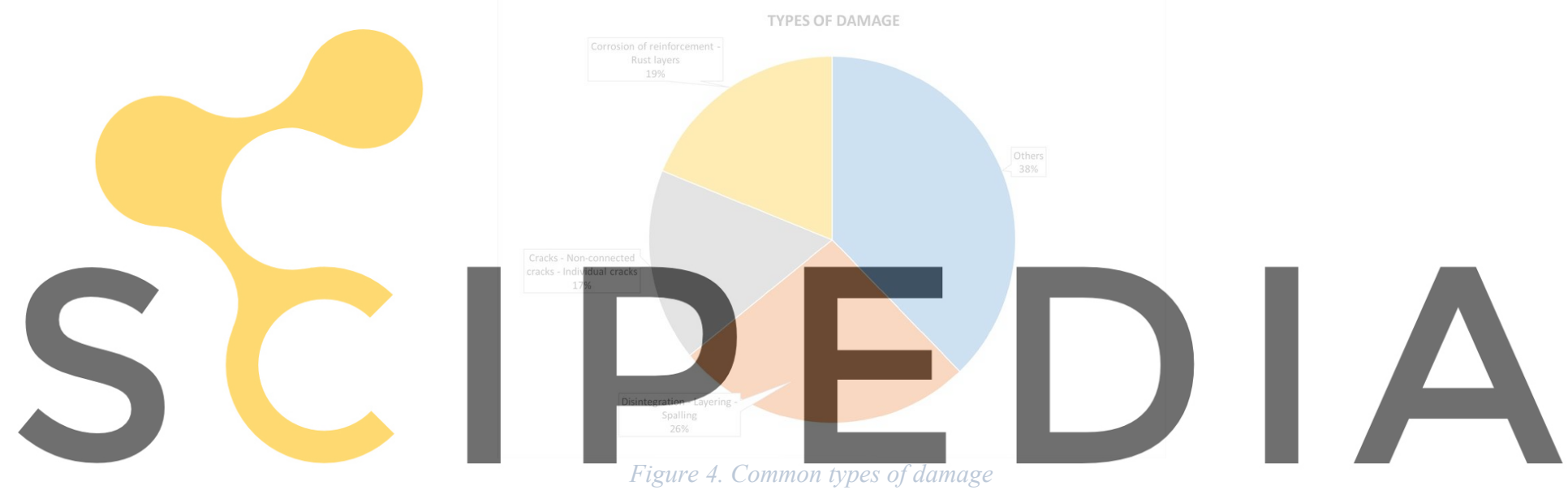

Register for free at https//www.scipedia.com to download the version without the watermark

- $90 \%$ of the damage processes were related to moisture-related issues, including corrosion, biological growth, surface condensation, and salt crystallization (Figure 5).

- It was assessed that $61 \%$ of the damage processes were related to carbonation-induced corrosion. This was supposed since the cracks and spalling observed were aligned with the reinforcement, there were no indication of chloride attack (e.g. pitting corrosion), and no structural issues were found (Figure 5). 


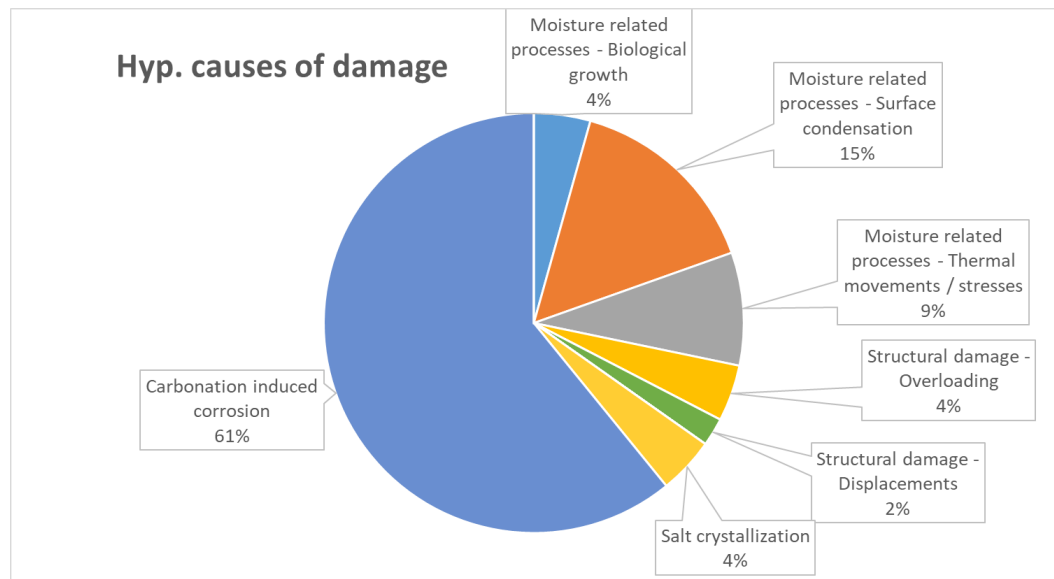

Figure 5. Common hypothetical causes of damage

To assess the state of conservation of the building, an index of "level of severity" was calculated. The different types of damage were multiplied by different coefficients depending on their extent and intensity of the damage, according to Equation 1. The resulting number provided an estimation, based on visual assessment, of the level of severity of the damage in the building, where the higher the number, the worse was the general condition.

Different parameters were then analysed against the level of severity to determine the factors

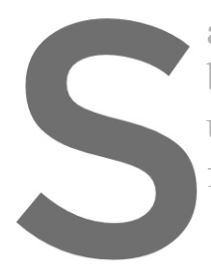
affecting the degradation

buildings and the number of understand the relation from zero (very good con
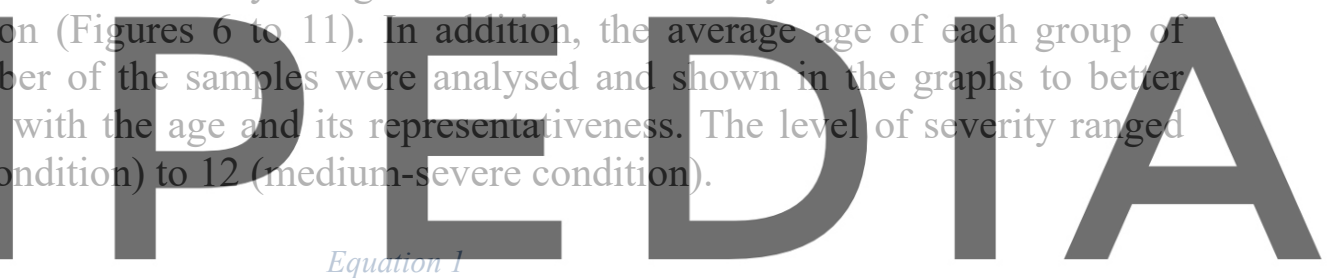

Register for free at https//www.scipedia.com to download the version without the watermark

Where: $L I=\sum_{i=1} n_{i} * E_{i} * S_{i}$

$L I$ is the Level of severity used in Figures (6 to 11).

$n_{i}$ is the number of cells marked in the same column of the template sheet, corresponding to the damages observed during the visual assessment (refer to Figure 3).

$E i$ is the coefficient regarding the extent of the damage as shown in Table 1.

$\mathrm{Si}$ is the coefficient regarding the severity of the damage as shown in Table 2.

Table 1. Coefficient regarding extent of damage

\begin{tabular}{|l|c|c|c|}
\cline { 2 - 4 } \multicolumn{1}{c|}{} & \multicolumn{3}{c|}{ Extent in the surface of the element } \\
\cline { 2 - 4 } \multicolumn{1}{c|}{} & $<1 / 3$ & $1 / 3<\mathrm{x}<2 / 3$ & $>2 / 3$ \\
\hline $\begin{array}{l}\text { Coefficient } \mathbf{E} \\
\text { (Extent of damage) }\end{array}$ & 1 & 2 & 3 \\
\hline
\end{tabular}


Table 2. Coefficient regarding the severity of the damage

\begin{tabular}{|l|c|c|c|}
\cline { 2 - 4 } \multicolumn{1}{c|}{} & \multicolumn{3}{c|}{ Severity of the damage } \\
\cline { 2 - 4 } \multicolumn{1}{c|}{} & Light & Medium severe & Very Heavy \\
\hline $\begin{array}{l}\text { Coefficient } \mathbf{S} \\
\text { (Severity of damage) }\end{array}$ & 1 & 2 & 3 \\
\hline
\end{tabular}

Regarding the relation between age and level of severity, the results showed a scattered distribution without a clear correlation (Figure 6). However, when linear trend line is plotted (Coefficient of determination $\mathrm{R}^{2}=9 \%$ ), it is evident a weak correlation between age and level of severity, where the older the building, the worse is the condition.

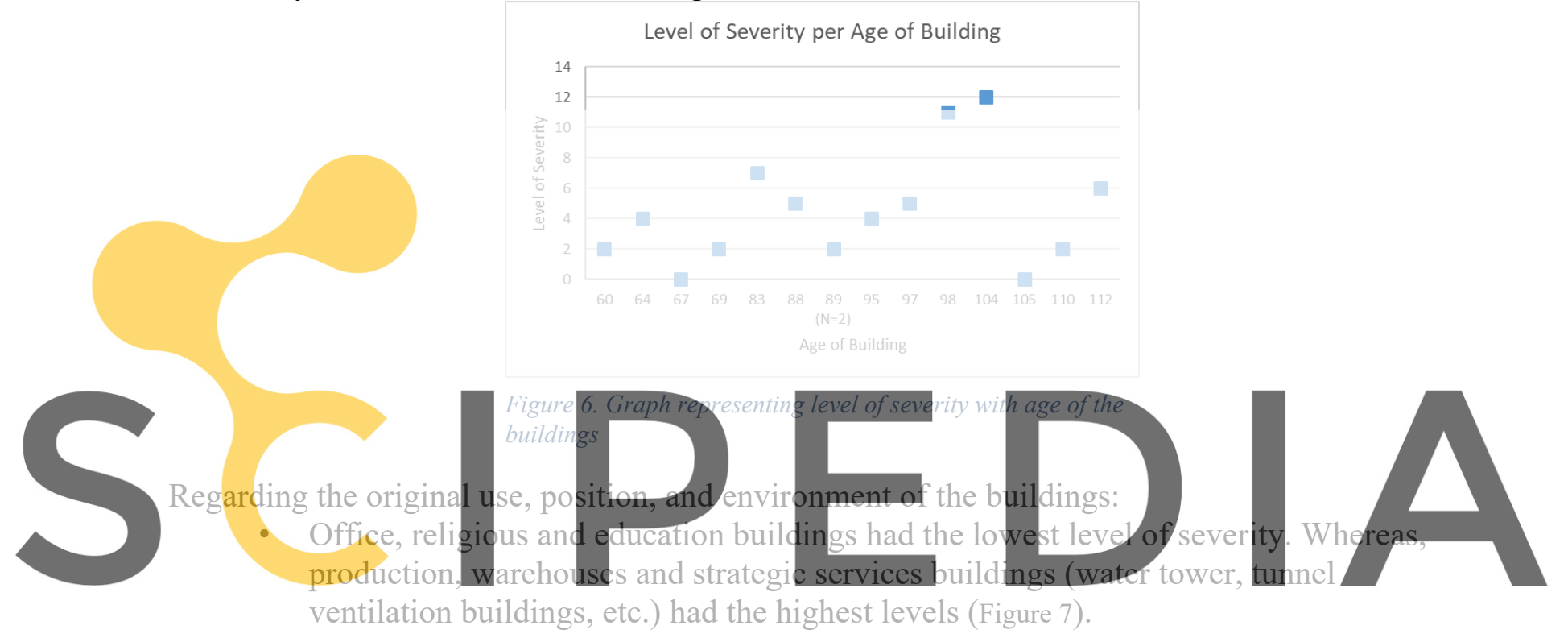

Register for free at https//www.scipedia.com to download the version without the watermark

Level of Severity per Original Use

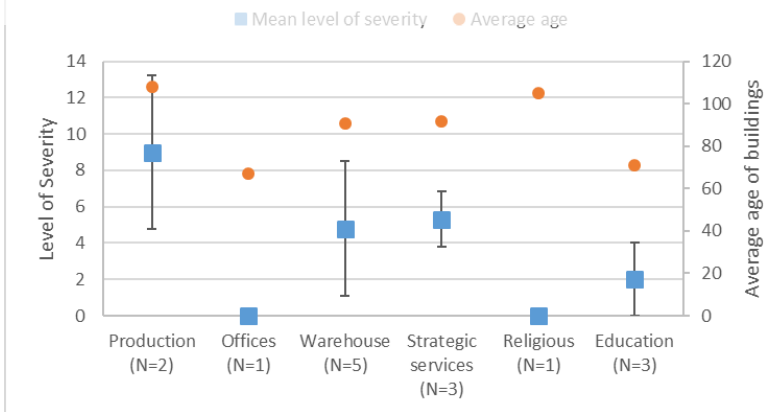

Figure 7. Graph representing level of severity per original uses of the buildings. "N" denotes number of buildings; orange dots represent mean age of buildings under the same category
Level of Severity per Environmental Condition

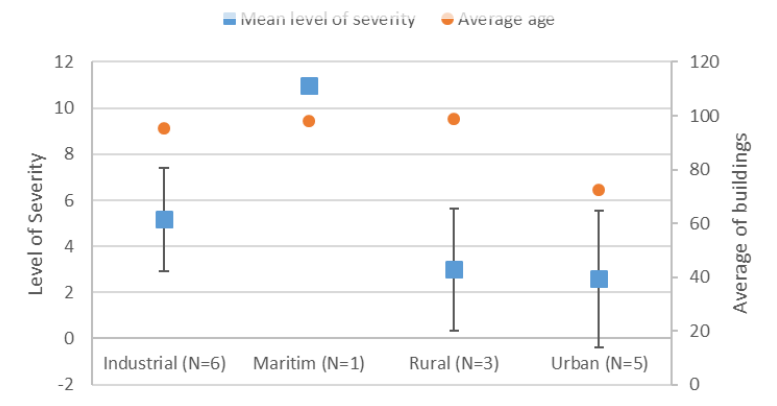

Figure 8. Graph representing level of severity per environmental condition of the buildings. " $N$ " denotes number of buildings; orange dots represent mean age of buildings under the same category

- Damage to buildings located in maritime and industrial environment did show a higher level of severity than buildings located in urban and rural areas, all having 
similar average age (Figure 8).

Regarding the monumental status (listed) and ownership of the building:

- Whether the buildings had monumental status or not did not have a noticeable impact on the level of severity.

- However, a tendency was noted regarding the ownership of the building (Figure 9). Damage in public buildings had in average a higher level of severity than private buildings, even though public buildings were on average slightly younger than private buildings.

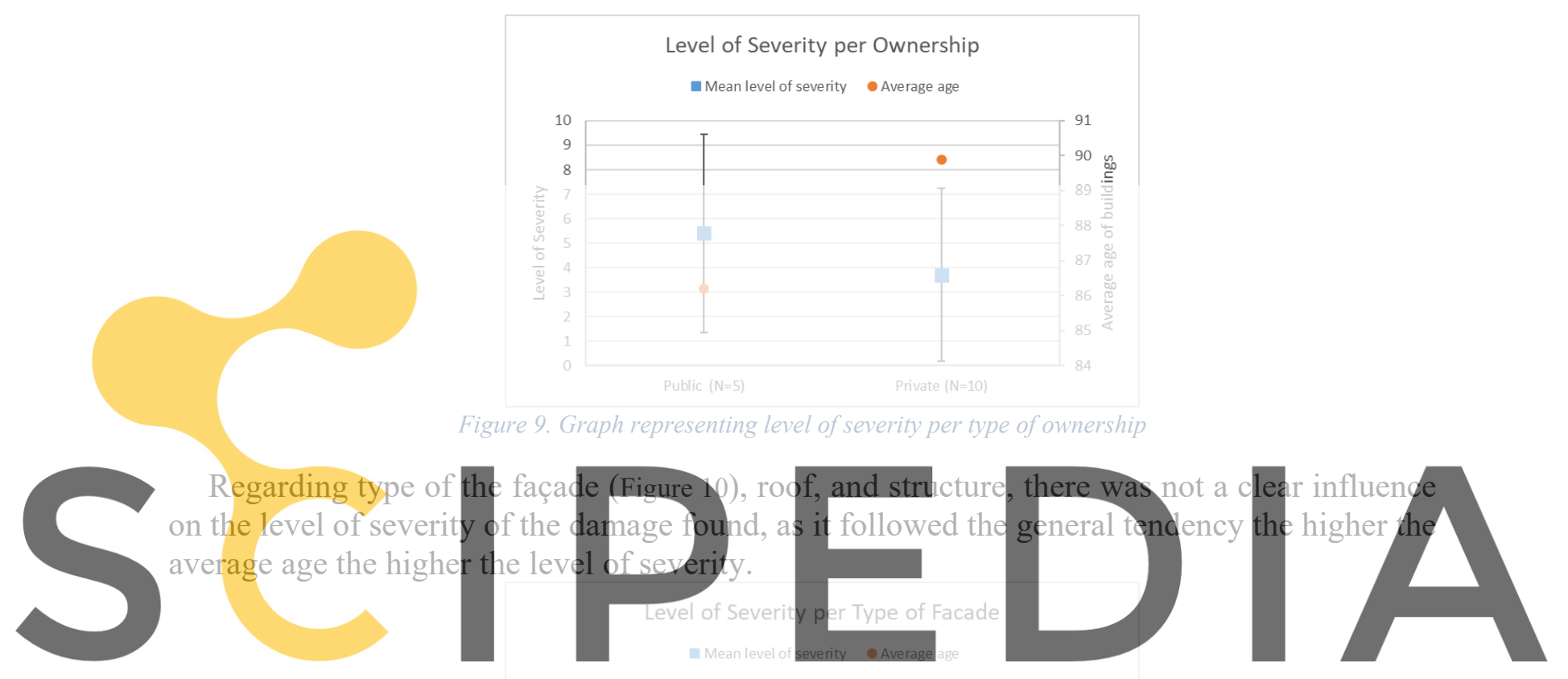

Register for free at https//www.scipedia.com to download the version without the watermark

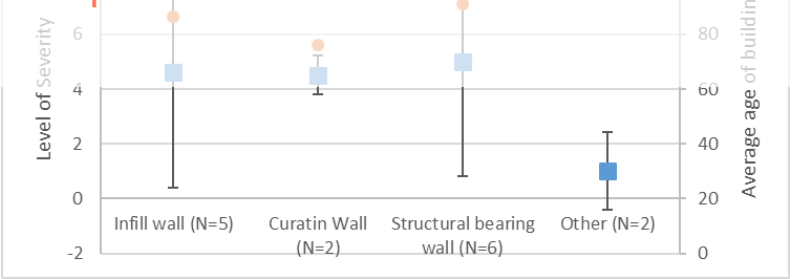

Figure 10. Level of severity per type of facade

Lastly, the reinforced concrete elements exposed to the outdoors rendered with a cement plaster had on average better performance than the exposed elements with no plaster or paint (Figure 11). It is important to note that the plastered elements had higher mean age than the nonplastered elements. On the other hand, the not-exposed elements, which are protected to weather and rain, resulted in higher level of severity. The main reason for this apparently incongruent result lays in the fact that one of the two case studies under this category was a leather fabric, where water and other chemicals were likely used inside the building. 


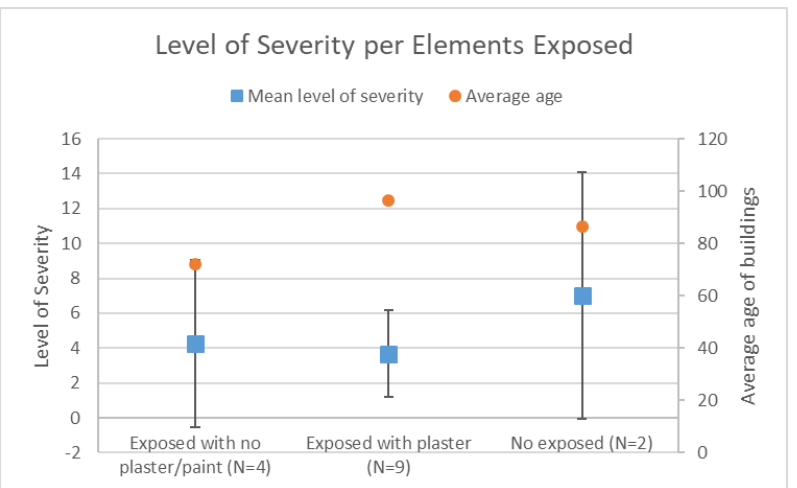

Figure 11. Level of severity per characteristics of exposed RC elements

\section{DISCUSSION AND CONCLUSIONS}

The current research is framed within the European project CONSECH20, which involves 5 participant countries and over 50 case studies. In this paper, a first sample of $15 \mathrm{RC}$ buildings in the Netherlands built before 1960s has been studied. A background investigation of the building characteristics was carried along with a visual survey, to quantify the most common types of damage, extent and severity.

A standardized template was created to minimize misinterpretations and homogenise the data among the different countries. An indicator of level of severity was calculated and confronted

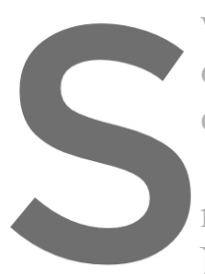
with different buildin

ownership, environmen conservation of the con

From the results of the

main damage proces
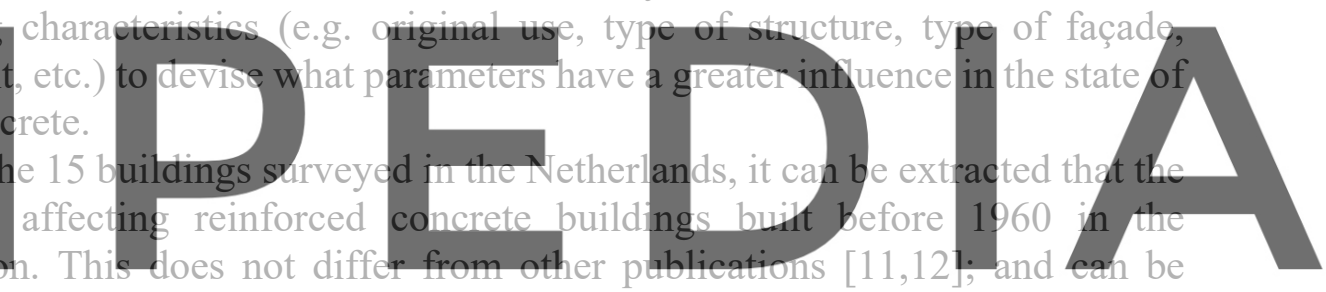

attributed to a combination of thin concrete covers, higher permeability, and imperfection in

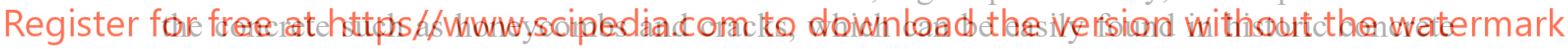
buildings.

The foremost hypothetical cause of corrosion is carbonation-induced corrosion. The subsequent most common types of damage were non-connected cracks, rust layers and spalling. Other types of damage were generally not significant, almost aesthetical, and barely affected the serviceability of the buildings.

Based on this research, the following parameters seem to be relevant for the durability of the reinforced concrete:

- Industrial and maritime environments. Industrial areas tend to have higher concentrations of $\mathrm{CO}_{2}$, which can increase the rate of carbonation in concrete. If the concrete cover is not thick enough, as is the case in some historic concrete buildings, the passivity layer protecting the reinforcement is destroyed due to carbonation. In addition the higher levels of pollution in these zones can increase the concentration of sulphates in the concrete [13], leading to other types of damage in the cement matrix such as the formation of ettringite [14]. In addition, high $\mathrm{RH}$, as in the case of maritime zones, translates into higher moisture content (MC) in concrete. MC is the main factor influencing the electrical resistivity [15], or in other words, the higher 
the $\mathrm{MC}$ in concrete, the lower the electrical resistivity and the higher corrosion rate [16-18]. In addition, if the building is within the splashing zone of seawater, the amount of chlorides ions in the concrete may increase, affecting the passivity layer of the reinforcement.

- Use of the building: Industrial and civil infrastructure buildings show more and severer damage types than the other building types. The increase of damages may be explained due to the discontinuity in the building use. In fact, the historical research revealed that $100 \%$ of the buildings constructed as warehouses or production factories were abandoned for more than 10 years in their lifetime. As any other building, the lack of the maintenance of historic concrete buildings has a great impact on the durability of concrete [19].

- External sacrificial plaster: Exposed RC elements with a cement-based plaster exhibited better performance against corrosion and other damage processes than $\mathrm{RC}$ elements without additional plaster. Rendering the exposed exterior concrete was a common practice in the Netherlands until the 1930s, apparently to hide the dull and rough aspect of raw concrete [4]. This is in line with the results of the case studies, since $100 \%$ of the buildings built before 1937 had a layer of plaster applied to the external concrete surfaces. A plaster layer can provide an additional protection against the ingress of $\mathrm{CO}_{2}$, moisture, and other soluble substances, which may lead to corrosion and other damages in the concrete [20]. However, if the corrosion has

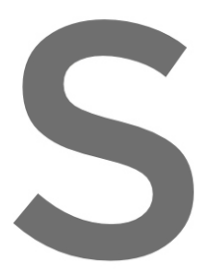
already initiated, as it may be the case in historic concrete, the corrosion
but the corrosion rate may decrease [21].
Ownership: In view of the rosults, private buildings are in gendral in bett
than publid buildings. Private buildings tend to have a mote lucrativ
therefore the quality and appearande of the buildings tend to be bette
maintained. As a new approach to tackle this -issue, nublie-private part

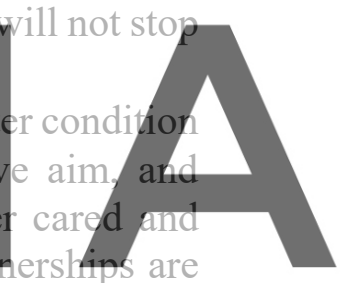

being used in different countries to help governments to manage the increasing costs

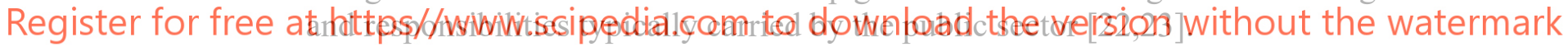

With a limited number of buildings, 15 cases in the Netherlands, this paper investigates different indicators to understand the chief factors affecting the degradation of historic concrete. As part of a larger project, this research aims to establish the basis for a greater understanding of the different factors affecting historic concrete buildings.

The main conclusions are:

1. Higher $\mathrm{RH}, \mathrm{CO}_{2}$ concentrations and levels of pollution, typically found in industrial and maritime environments, tend to decrease the durability of historic concrete.

2. A continuous use and maintenance guarantees that RC buildings, even over 100 years old, can extend their service lifespan.

3. Cement plasters in exposed elements can reduce the level of severity of the damages in the concrete.

4. Public buildings tend to be in worse condition than private ones. 


\section{ACKNOWLEDGEMENTS}

This paper is framed within the JPI European project CONSECH20 Conservation of 20th century concrete Cultural Heritage in urban changing environments.

\section{REFERENCES}

[1] I. Marcos, J.T. San-José, A. Santamaría, L. Garmendia, Early Concrete Structures: Patented Systems and Construction Features, in: Struct. Anal. Hist. Constr., 2016: pp. 310-319. https://doi.org/10.1080/15583058.2017.1323241.

[2] G. Pardo Redondo, D. Friedman, B. De Miguel Alcalá, El ingeniero restaurador y los edificios de Nueva York, Loggia, Arquit. Restauración. (2017) 94. https://doi.org/10.4995/loggia.2017.6559.

[3] S.E. Wermiel, WERMIEL Sara CaliforniaConcrete-revised layouted, Proc. Third Int. Congre Ss Constr. Hist. Cottbus, May 2009. (2009).

[4] H.A. Heinemann, Historic Concrete. From concrete repair to concrete conservation, TU Delft, 2013. https://doi.org/9789052694115.

[5] C.L. Page, K. Treadaway, Aspects of the electrochemistry of steel in concrete, Nature. (1982) 109-115. https://doi.org/https://doi.org/10.1038/297109a0.

[6] C. Baggio, A. Bernardini, R. Colozza, L. Corazza, M. Della Bella, G.D.I. Pasquale, M. Dolce, A. Goretti, A. Martinelli, G. Orsini, F. Papa, G. Zuccaro, Field Manual for postearthquake damage and safety assessment and short term countermeasures ( AeDES ), 2007.

[7] Applied Technology Council (ATC), ATC-20 Detailed Evaluation Safety Assessment Form, (2005). https://www.atcouncil.org/atc-20.

[8] B. Taskin, K. Guler, U.M. Tugsal, M. Gencoglu, M. Celik, Z. Hasgur, M. Aydogan, A.I. Saygun, A Novel Post-Earthquake Damage Survey Sheet : Part I- RC Buildings, (2011).

[9] Applied Technology Council (ATC), Rapid Visual Screening of Buildings for Potential Seismic Hazards: A Handbook, Washington, DC, 2015. https://www.fema.gov/medialibrary-data/1426210695633-d9a280e72b32872161efab26a602283b/FEMAP154_508.pdf.

[10] A.S. Arya, A. Agarwal, Rapid Visual Screening of RCC Buildings, India, 2002.

[11] C. Andrade, Propagation of reinforcement corrosion: principles, testing and modelling, Mater. Struct. 52 (2019) 2. https://doi.org/10.1617/s11527-018-1301-1.

[12] C. Van Steen, L. Koptsopoulou, E. Verstrynge, Historical and Structural Analysis of a Deteriorated Reinforced Concrete Structure: Student Residence Camilo Torres in Leuven (Belgium), RILEM Bookseries. 18 (2019) 2304-2313. https://doi.org/10.1007/978-3-319-99441-3_247.

[13] E. Marie-Victoire, M. Bouichou, T. Congar, R. Blanchard, Concrete cultural heritage in France - inventory and state of conservation, in: Concr. Repair, Rehabil. Retrofit. IV, 2015: pp. 343-350. https://doi.org/10.1201/b18972-49.

[14] M. Zhang, J. Chen, Y. Lv, D. Wang, J. Ye, Study on the expansion of concrete under attack of sulfate and sulfate - chloride ions, Constr. Build. Mater. 39 (2013) 26-32. https://doi.org/10.1016/j.conbuildmat.2012.05.003.

[15] D.A. Koleva, Corrosion and protection in reinforced concrete: Pulse cathodic 
protection: an improved cost-effective alternative, (2007).

https://repository.tudelft.nl/islandora/object/uuid\%3A1d2af376-e92e-4864-91e4499e53c83e75 (accessed June 15, 2019).

[16] P. Azarsa, R. Gupta, Electrical Resistivity of Concrete for Durability Evaluation: A Review, Adv. Mater. Sci. Eng. 2017 (2017) 1-30. https://doi.org/10.1155/2017/8453095.

[17] G. Markeset, R. Myrdal, Modelling of Reinforcement Corrosion in Concrete - State of the art, 2008. https://doi.org/10.1002/maco.200603899.

[18] M. Stefanoni, U.M. Angst, B. Elsener, Electrochemistry and capillary condensation theory reveal the mechanism of corrosion in dense porous media, Sci. Rep. (2018). https://doi.org/10.1038/s41598-018-25794-x.

[19] S. Macdonald, A.P. Arato Goncalves, Conservation Principles for Concrete of Cultural Significance, Los Angeles, 2020.

[20] Entreprise of the European Commission, REHABCON Manual. Strategy for maintenance and rehabilitation in concrete structures, 2004.

[21] Tekniska högskolan i Lund. Division of Building Materials., REHABCON Strategy for maintenance and rehabilitation in concrete structures. Work Package 2.3: evaluations of alternative repair and upgrading options: Final Report, Tekniska högskolan i Lund. Division of Building Materials., Lund, Sweden, 2004.

[22] S. Macdonald, C. Cheong, The Role of Public-Private Partnerships and the Third Sector in Conserving Heritage Buildings, Sites, and Historic Urban Areas, The Getty Conservation Institute, Los Angeles, 2014.

[23] N. Zahirah, M. Azizi, A. Abdul, M. Azizi, M. Din, Recurring Issues in Historic Building Conservation, Procedia - Soc. Behav. Sci. 222 (2016) 587-595. https://doi.org/10.1016/j.sbspro.2016.05.217. 